JOURNAL of

TOXICOLOGY and

ENVIRONMENTAL

HEALTH
Journal of Toxicology and Environmental Health, Part A Current Issues

\title{
Cytogenetic and Immunological Effects Associated with Occupational Formaldehyde Exposure
}

\section{Solange Costa , Julia García-Lestón, Marta Coelho , Patrícia Coelho , Carla Costa , Susana Silva, Beatriz Porto, Blanca Laffon \& João Paulo Teixeira}

To cite this article: Solange Costa , Julia García-Lestón , Marta Coelho , Patrícia Coelho , Carla Costa , Susana Silva , Beatriz Porto , Blanca Laffon \& João Paulo Teixeira (2013) Cytogenetic and Immunological Effects Associated with Occupational Formaldehyde Exposure, Journal of Toxicology and Environmental Health, Part A, 76:4-5, 217-229, DOI: 10.1080/15287394.2013.757212

To link to this article: https://doi.org/10.1080/15287394.2013.757212

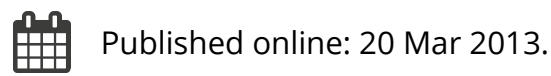

Submit your article to this journal 준

III Article views: 542

Citing articles: 19 View citing articles $\widetilde{ }$ 
Journal of Toxicology and Environmental Health, Part A, 76:217-229, 2013

Copyright $\odot$ Taylor \& Francis Group, LLC

ISSN: $1528-7394$ print / 1087-2620 online

DOI: $10.1080 / 15287394.2013 .757212$

\title{
CYTOGENETIC AND IMMUNOLOGICAL EFFECTS ASSOCIATED WITH OCCUPATIONAL FORMALDEHYDE EXPOSURE
}

\author{
Solange Costa ${ }^{1}$, Julia García-Lestón ${ }^{2}$, Marta Coelho ${ }^{1}$, Patrícia Coelho ${ }^{1,3}$, Carla Costa ${ }^{1,4}$, \\ Susana Silva ${ }^{1}$, Beatriz Porto ${ }^{5}$, Blanca Laffon ${ }^{2}$, João Paulo Teixeira ${ }^{1,3}$ \\ ${ }^{1}$ National Institute of Health, Environmental Health Department, Porto, Portugal \\ ${ }^{2}$ Toxicology Unit, Department of Psychobiology, University of A Coruña, Edificio de Servicios \\ Centrales de Investigación, A Coruña, Spain \\ ${ }^{3}$ ICETA, Institute of Agricultural and Agri-foodstuffs Sciences and Technologies, University of \\ Porto, Porto, Portugal \\ ${ }^{4}$ ISPUP, Institute of Public Health, University of Porto, Porto, Portugal \\ ${ }^{5}$ ICBAS, Biomedical Sciences Institute of Abel Salazar, University of Porto, Porto, Portugal
}

Formaldehyde (FA) is a widely used industrial chemical for which exposure is associated with nasopharyngeal and sinonasal cancer. Based on sufficient evidence of carcinogenicity from human investigations, supporting studies on mechanisms underlying carcinogenesis, and experimental evidence in animals, FA status was recently revised and reclassified as a human carcinogen. The highest level of exposure to FA occurs in occupational settings. Although several studies reported FA ability to induce genotoxic responses in exposed workers, not all findings were conclusive. In addition, published studies on the immunological effects of FA indicate that this compound may be able to modulate immune responses, although data in exposed subjects are still preliminary. In this study a group of pathology anatomy workers exposed to FA was evaluated for cytogenetic and immunological parameters. A control group with similar sociodemographic characteristics and without known occupational exposure to FA was also included. Genotoxicity was evaluated by means of micronucleus (MN) test, sister chromatid exchanges (SCE), and T-cell receptor (TCR) mutation assay. Percentages of different lymphocyte subpopulations were selected as immunotoxic biomarkers. The mean level of FA environmental exposure was $0.36 \pm 0.03 \mathrm{ppm}$. MN and SCE frequencies were significantly increased in the exposed group. A significant decrease of the percentage of B cells in the exposed group was also found. Data obtained in this study indicate that genotoxic and immunotoxic increased risk due to FA occupational exposure cannot be excluded. Implementation of effective control measures along with hazard prevention campaigns may be crucial to decrease the risk.

Formaldehyde (FA) is a high-volume production chemical produced globally with a large range of industrial and medical purposes. Listed, since 2004, by IARC as a human carcinogen (group 1), FA status was recently revised by the U.S. government, which reclassified this compound as known to be a human carcinogen (group A). Both reclassifications are based on sufficient evidence of carcinogenicity from human investigations, supporting studies on mechanisms underlying carcinogenesis, and experimental evidence in animals. Numerous epidemiological studies of occupational exposed populations demonstrated a causal relationship between exposure to FA and cancer (IARC, 2006; NTP, 2010).

This work is supported by Fundação para a Ciência e a Tecnologia (FCT) under the grants SFRH/BD/46929/2008 and PTDC/SAUESA $/ 102367 / 2008$.

Address correspondence to Solange Costa, National Institute of Health, Environmental Health Department; Rua Alexandre Herculano, 321, 4000-055 Porto, Portugal. E-mail: solange.costa2@gmail.com 
Consistent findings of increased risks of certain types of rare cancers, namely, nasopharyngeal and sinonasal cancer, were found among workers with higher measures of exposure to FA (exposure level or duration). The mechanisms by which FA induced cancer are not completely understood but most likely involve multiple modes of action, such as DNA reactivity, gene mutation, epigenetic effects, chromosomal breakage, aneuploidy, and oxidative stress (Lu et al., 2008; NTP, 2010). Zhang et al. (2010) suggested a potential causal association between occupational exposure to FA and excess mortality from leukemia, especially myeloid leukemia. However, due to mix results, evidence for FA leukemogenicity remains controversial (Checkoway et al., 2012). Given its economic importance and widespread use, many individuals are environmentally and/or occupationally exposed to FA. Nonoccupational exposure includes vehicles emissions, tobacco smoke, and household products. The highest level of human exposure to this aldehyde occurs in occupational settings. Occupational exposure involves not only individuals employed in the direct manufacture of FA and products containing it (Paustenbach et al., 1997), but also those using these products, such as those working in pathology anatomy labs where it is commonly used as a fixative and tissue preservative.

In the last decade a large number of toxicological studies were published regarding FA. FA-induced genotoxicity was confirmed in a variety of experimental systems ranging from bacteria to rodents. Although these positive findings may provide a basis for extrapolation to humans, the cytogenetic assays in humans have been conflicting with both positive and negative outcomes. Genotoxic endpoint analyses are of great interest in risk assessment of occupational carcinogens because they precede adverse health effects, thus offering a greater potential for preventive intervention (Mayeux, 2004). Genotoxicity evaluation constitutes a valuable tool for studying the most important occupational and environmental hazards to public health occurring in the past few decades and allows a reasonable epidemiological evaluation of cancer prediction (Bonassi et al., 2005; Laffon et al., 2006). Cytogenetic markers such as micronuclei $(\mathrm{MN})$ and sister chromatid exchange (SCE) are well-established endpoints that were extensively used for assessing DNA damage at the chromosomal level in human biomonitoring studies (Carrano and Natarajan, 1988; Fenech, 1993).

Evaluation of potential adverse effects on the immune system is also an important component of the overall evaluation of a compound toxicity (Luebke et al., 2006). The immune response is a complex process involving the interaction of various components from anatomical barriers to specialized cells. This interaction among the various components of the immune system is extremely advantageous for the organism as the continuing dialogue between innate and acquired immune response, and efficiency is ensured. A number of biological or chemical agents have the ability to alter the functionality of the immune system, potentially compromising the organism's ability to recognize, control, or eliminate infectious agents or neoplastic cells (Veraldi et al., 2006). Studies on immunological effects induced by FA predominantly focused on the allergic reactions such as contact dermatitis and occupational asthma. In fact, a few investigations on immunological parameters (Tang et al., 2009, Hosgood et al. 2012) suggested that FA may alter these endpoints in exposed individuals.

The aim of the present study was to evaluate both genotoxic and immunotoxic parameters using peripheral lymphocytes of FA-exposed workers employed in pathology anatomy labs. Air sampling was performed in order to determine FA levels of exposure in each worker. Genotoxic damage was studied by means of MN test, " and T-cell receptor (TCR) mutation assay. Percentages of major lymphocyte subsets, namely, $\mathrm{T}$ lymphocytes $\left(\% \mathrm{CD}^{+}\right)$, T-helper lymphocytes $\left(\% \mathrm{CD}^{+}\right)$, T-cytotoxic lymphocytes $\left(\% \mathrm{CD}^{+}\right), \mathrm{B}$ lymphocytes $\left(\% \mathrm{CD} 19^{+}\right)$, and natural killer (NK) cells $\left(\% \mathrm{CD} 16-56^{+}\right)$, were selected as immunotoxicity markers. 


\section{METHODS}

\section{Subject Selection and Blood Sample Collection}

The study population consisted of 35 subjects working for at least $1 \mathrm{yr}$ in 4 hospital pathology anatomy labs, located in Portugal, and 35 nonexposed control employees, working in the same area in administrative offices but without occupational exposure history to formaldehyde (FA). The characteristics of both groups are described in Table 1. Relevant individual information on age, smoking habits, health conditions, medical history, medication, and diagnostic tests (x-rays etc.) was assessed by means of questionnaires. Subjects that stopped smoking for more than $2 \mathrm{yr}$ were considered nonsmokers. Workers also provided information related to working practices such as use of protective measures, years of employment, specific symptoms related to FA exposure and chronic respiratory diseases and other disorders. Ethical approval for this study was obtained from the Ethical Board of the National Institute of Health. All subjects were fully informed about the procedures and aims of this study and each subject prior to the study signed an informed consent form. Peripheral blood samples were collected by venipuncture from each donor between 10 and 11 a.m. All samples were coded and analyzed under blind conditions.

\section{Environmental Monitoring}

Air sampling was performed in the workers breathing zone for representative working periods. Analysis of the samples allowed the calculation of the 8-h time-weighted average (TWA) level of exposure to FA for each subject. Air sampling and FA analysis were performed according to the NIOSH method number 3500 (NIOSH, 1994).

\section{Micronucleus (MN) Test}

Aliquots of $0.5 \mathrm{ml}$ of heparinized whole blood were used to establish duplicate lymphocyte cultures for cytokinesis-blocked MN test as described by Teixeira et al. (2004). Microscopic analyses were performed using a Nikon Eclipse E400 light microscope. To determine the total number of $M N$ in binucleated cells, a total of 1000 binucleated cells with well-preserved cytoplasm (500 per replicate) was scored for each subject. MN were scored blindly by the same reader and identified according to the criteria defined by Fenech (2007).

\section{Sister Chromatid Exchanges (SCE)}

Lymphocyte cultures for SCE were established in duplicate as described by Teixeira et al. (2004). Differential chromatid staining

TABLE 1. Characteristics of the Study Population

\begin{tabular}{llcc}
\hline & Control $(n=35)$ & Exposed $(n=35)$ & $p$ Value \\
\hline Gender & & & \\
$\quad$ Females & 31 & 28 & $.513^{b}$ \\
$\quad$ Males & 4 & $41.2 \pm 8.7(26-56)$ & $.527^{c}$ \\
Age $(\mathrm{yr})^{a}$ & $39.8 \pm 10.0(24-61)$ & $12.5 \pm 8.1(1-30)$ & $.464^{c}$ \\
Years of employment ${ }^{\mathrm{a}}$ & - & $23.4 \pm 3.3(17-32)$ & \\
BMI (kg/m $\left.{ }^{2}\right)^{a}$ & $24.1 \pm 4.8(19-38)$ & $28(80 \%)$ & $7(20 \%)$ \\
Smoking status & & $12.9 \pm 11.2(0.6-35.0)$ & $.863^{c}$ \\
$\quad$ Nonsmokers & $28(80 \%)$ & & \\
$\quad$ Smokers & $7(20 \%)$ & & \\
$\quad$ Packs per year & $13.9 \pm 10.3(2.8-32.3)$ & & \\
\hline
\end{tabular}

${ }^{a}$ Mean \pm SD (range).

${ }^{b}$ Fisher's exact test.

'Student's t-test. 
was performed with the fluorescence-plusGiemsa procedure (Perry and Wolff, 1974). Microscopic analyses were performed using a Nikon Eclipse E400 light microscope. A single observer scored 50 second-division metaphases for each donor (25 from each duplicate culture) on coded slides to determine the number of SCE per cell.

\section{TCR Mutation Assay}

Peripheral blood mononuclear leukocytes were isolated in BD Vacutainer Cell Preparation Tubes (CPT) with sodium heparin according to the manufacturer's instructions. After centrifugation, cells were washed thrice with ice-cold $\mathrm{pH} 7.4$ phosphate buffer solution. TCR mutation assay was performed by a flow cytometric methodology according to Akiyama et al. (1995) with minor modifications (García-Lestón et al., 2011). Cell suspensions were analyzed by a FACScalibur flow cytometer with Cell Quest Pro software (Becton Dickinson). A minimum of $2.5 \times 10^{5}$ lymphocyte-gated events was acquired, and mutation frequencies of TCR (TCR-Mf) were calculated as the number of events in the mutant cell window $\left(\mathrm{CD}^{-}{ }^{-} \mathrm{CD} 4^{+}\right.$ cells) divided by the total number of events corresponding to $\mathrm{CD}^{+}{ }^{+}$cells.

\section{Lymphocyte Subpopulations}

Cell percentages of total $\mathrm{T}$ lymphocytes $\left(\% \mathrm{CD}^{+}\right)$, $\mathrm{T}$-helper $(\mathrm{Th})$ lymphocytes $\left(\% \mathrm{CD}^{+}\right)$, T-cytotoxic (Tc) lymphocytes $\left(\% \mathrm{CD}^{+}\right), \quad \mathrm{B}$ lymphocytes $\left(\% \mathrm{CD} 19^{+}\right)$, and natural killer (NK) cells $\left(\% \mathrm{CD} 16-56^{+}\right)$were determined by flow cytometric measurements using a three-color direct immunofluorescence surface marker methodology described by GarcíaLestón et al. (2011). Analyses were carried out in a FACScalibur flow cytometer using Cell Quest Pro software (Becton Dickinson). After gating the lymphocytes based on forward/side scatter plots, fluorescence data from FL1 (FITC), FL2 (PE), and FL3 (PECy5) were obtained. At least 104 events in the lymphocytes window were acquired.

\section{Statistical Analysis}

All analyses were conducted using the SPSS for Windows statistical package 16.0. The statistical differences between means and the relationship between categorical variables in the characteristics of the study population were assessed by means of Student's t-test and Fisher's exact test, respectively. All results obtained in the study were assessed for normal distribution using the Kolmogorov-Smirnov test and graphic evaluation (histograms, Q$\mathrm{Q}$ plots, P-P plots). When the assumption of normality was not fitted, data were transformed to normalize the distribution. TCRMf, B lymphocytes, NK cells, and Th/Tc ratio were the only parameters that departed significantly from normality and therefore these data were transformed on the natural logarithm scale (In). The effect of exposure on the level of genotoxicity and immunological biomarkers was preliminarily tested using Student's t-test. Multivariant analysis was carried out to evaluate the contribution of exposure and potential confounding factors to the response variables considered. Correlation between variables was analyzed by Pearson's correlation test. The level of significance considered was .05.

\section{RESULTS}

The general characteristics of the studied population are summarized in Table 1. In total, 70 subjects (35 exposed and 35 controls) were involved in the study. Both groups were similar in gender distribution, age, body mass index (BMI), and smoking habits. The mean level of worker's exposure to formaldehyde (FA) was $0.36 \pm 0.03 \mathrm{ppm}$ (range $0.23-0.69 \mathrm{ppm}$ ). The peak emission of FA occurred during two routine tasks: macroscopic examination of FA-preserved specimens, and disposal of specimens and waste solutions. The current Portuguese occupational exposure limit is $0.3 \mathrm{ppm}$ (ceiling level), indicating this is the maximum safe FA concentration that should never be exceeded during any length of time in a worker's breathing zone. The American Conference of Governmental 
Industrial Hygienists (ACGIH) also set a ceiling exposure limit of 0.3 ppm (ACGIH, 2008). Our results show that workers in the pathology anatomy labs analyzed were exposed to airborne concentrations of FA that exceeded the national guideline limit value and ACGIHrecommended exposure criteria.

The genotoxicity biomarkers results are shown in Figure 1 as a univariant analysis. MN frequency was significantly 2.5 -fold higher in FA-exposed workers than in unexposed individuals. In addition, SCE mean value was significantly increased in exposed group by 1.3 -fold. A positive significant correlation was found between these two cytogenetic biomarkers. TCR-Mf did not differ markedly between exposed and control subjects.

Data obtained from univariant analysis of lymphocyte subpopulations in FA-exposed subjects and controls are illustrated in Figure 2. No significant differences were found for $T$ cells_total \%CD3 ${ }^{+} \mathrm{T}$ lymphocytes, \%CD4 ${ }^{+} \mathrm{T}$ helper cells (Th), \%CD8 ${ }^{+}$T cytotoxic cells (Tc), Th/Tc ratio-and for \%CD16-56 ${ }^{+}$NK cells. However, a significant decrease of 0.7 -fold in $\% \mathrm{CD}^{1} 9^{+} \mathrm{B}$ lymphocytes was noted in exposed individuals.

Table 2 summarizes the results obtained in the multivariant analysis of the effect biomarkers, taking into account lifestyle factors, including age, gender, and smoking habits, in addition to exposure. It should be noted that only significant results are shown. The significant effect of exposure was confirmed in the MN test and SCE as increases and in

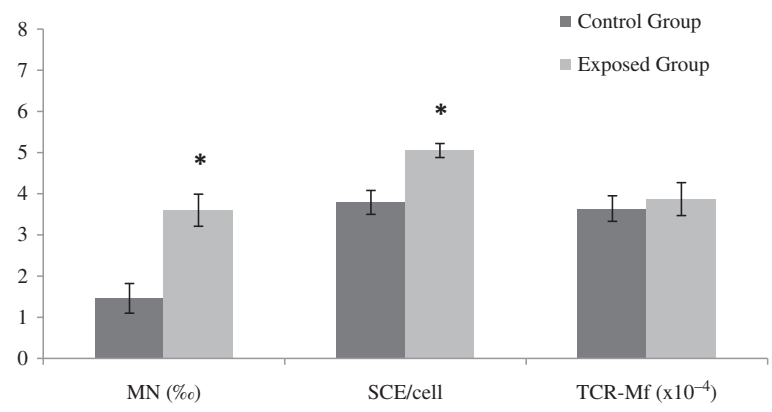

FIGURE 1. Results of MN test, SCE, and TCR mutation assay in the study population. Asterisk indicates significantly different from control group, $p<.05$, according to Student's $t$-test.
$\% \mathrm{CD}^{+}{ }^{+} \mathrm{B}$ lymphocytes as a decrease. Further, a significant correlation was obtained between frequencies of $\mathrm{MN}$ and SCE, and a nearly significant correlation was found between SCE and $\% \mathrm{CD} 19^{+}$. A significant effect of age was observed on SCE frequency; a rise was also detected for $\mathrm{MN}$ rate that did not reach significance. Indeed, a significant positive correlation was found between age and SCE frequency. No significant influence of gender or smoking habits was observed. Besides, exposure time (years of employment) was not significantly correlated with any genotoxicity or immunological parameters.

When considering the FA environmental levels corresponding to each exposed individual, a significant influence of the FA level of exposure was found for some lymphocyte subpopulations based upon significant results collected in Table 3. Total \%CD3 ${ }^{+}$ $\mathrm{T}$ lymphocytes and \%CD4 ${ }^{+}$Th cells was significantly elevated with FA-level of exposure, whereas \%CD16-56+ NK cells was significantly reduced. In fact, these results agree with the correlations found between the FA-exposure levels and \%CD3 ${ }^{+}, \% \mathrm{CD} 4^{+}$, and \%CD16$56^{+}$NK cells. Significant correlations were also observed between \%CD16-56 ${ }^{+}$NK cells and $\% \mathrm{CD} 3+\mathrm{T}$ lymphocytes and \%CD4+ Th cells. No significant effect of gender, smoking habits, or age was noted in these studies.

\section{DISCUSSION}

In pathology anatomy labs, FA is a wellknown compound traditionally used as a fixative and tissue preservative. Indoor air analyses consistently show that the levels of airborne FA in pathology anatomy labs exceeded recommended exposure criteria (Shaham et al., 2002; Akbar-Khanzadeh and Pulido, 2003). In these settings, absorption of FA occurs mainly through inhalation. Inhaled FA primarily affects the upper airways; the severity and extent of physiological response depend upon chemical concentration in the air. In the current study the mean FA level of exposure found, 0.36 $\pm 0.03 \mathrm{ppm}$, was higher than the established 


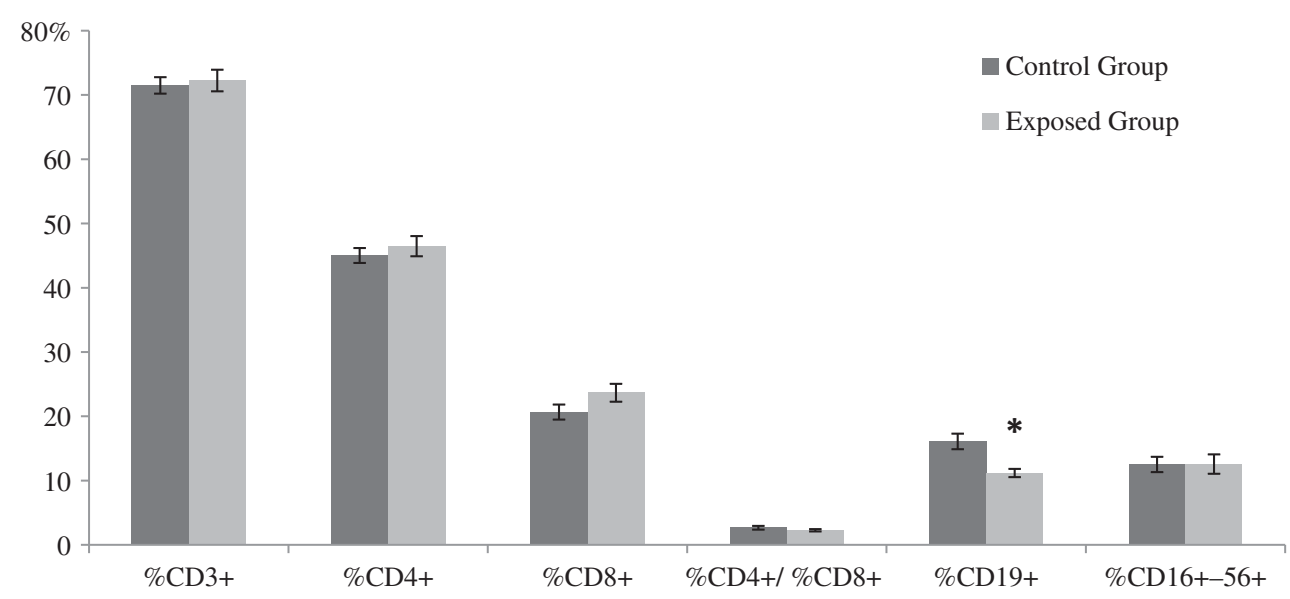

FIGURE 2. Percentages of lymphocyte subsets analyzed in the study population. Asterisk indicates significantly different from control group, $p<.05$, according to Student's $t$-test.

TABLE 2. Influence of Exposure, Gender, Smoking Habits, and Age on MN, SCE, and B Lymphocytes (\%CD19+)

\begin{tabular}{|c|c|c|c|c|c|}
\hline Model & $\begin{array}{l}\text { Unstandardized } \\
\text { coefficients } \beta\end{array}$ & $95 \% \mathrm{Cl}$ & $\begin{array}{l}\text { Partial } \\
p \text { value }\end{array}$ & $R^{2}$ & $\begin{array}{l}\text { Model } \\
p \text { value }\end{array}$ \\
\hline 1. $\mathrm{MN}(\% \mathrm{o})$ & & & & .232 & .002 \\
\hline Exposed vs. nonexposed & 2.1 & 1.025 to 3.174 & $<.001$ & & \\
\hline Females vs. males & 0.334 & 1.170 to 1.838 & .659 & & \\
\hline Smokers vs. nonsmokers & 0.061 & -1.302 to 1.423 & .929 & & \\
\hline Age (yr) & 0.05 & -0.008 to 0.109 & .088 & & \\
\hline 2. SCE/cell & & & & .250 & .001 \\
\hline Exposed vs. nonexposed & 1.245 & 0.594 to 1.897 & $<.001$ & & \\
\hline Females vs. males & 0.514 & -0.398 to 1.426 & .264 & & \\
\hline Smokers vs. nonsmokers & 0.28 & -0.546 to 1.106 & .501 & & \\
\hline Age $(y r)$ & 0.036 & 0.001 to 0.071 & .045 & & \\
\hline 3. B lymphocytes (\%CD19+) & & & & .174 & .014 \\
\hline Exposed vs. nonexposed & -1.387 & -1.714 to -1.121 & .003 & & \\
\hline Females vs. males & -1.097 & -1.477 to 1.228 & .536 & & \\
\hline Smokers vs. nonsmokers & 1.198 & -1.093 to 1.568 & .185 & & \\
\hline Age $(y r)$ & -1.007 & -1.019 to 1.004 & .228 & & \\
\hline
\end{tabular}

$p<0.05$, significantly different.

national ceiling limit of $0.3 \mathrm{ppm}$. It is important to note that $54 \%$ of the workers were exposed to FA levels greater than or equal to $0.3 \mathrm{ppm}$, and half of these were exposed to concentrations above $0.4 \mathrm{ppm}$. Therefore, data obtained show that workers are exposed to levels of FA that are greater than both national and international recommended limit values (IARC, 2006), indicating a potential risk to workers' health. The main FA vapor emissions occurred during macroscopic examination of FA-preserved specimens and during the disposal of specimens and waste solutions. In most cases during these tasks the workers were only using masks for biological hazard, not appropriate to protect from FA vapors. The primary reason given by workers for not using goggles and appropriate masks (when available) was interference in efficiency in performance of activities, namely, difficulties in communication, taking notes, and handling material. Implementation of security and hygiene measures, such as periodic air sampling and medical surveillance, as well as good practice campaigns may be crucial to lower the risk associated with FA occupational exposure.

As shown in Figure 1, frequencies of $M N$ and SCE were significantly elevated in FAexposed individuals compared to unexposed controls. The increase in $\mathrm{MN}$ formation in 
TABLE 3. Influence of FA Environmental Level, Gender, Smoking Habits, and Age on T Lymphocytes (\%CD3+), T-Helper Cells (\%CD4+), and NK Cells $\left(\% \mathrm{CD} 16-56^{+}\right)$, Only in the Exposed Population

\begin{tabular}{|c|c|c|c|c|}
\hline Model & $95 \% \mathrm{Cl}$ & $\begin{array}{l}\text { Partial } \\
p \text { value }\end{array}$ & $R^{2}$ & $\begin{array}{l}\text { Model } \\
p \text { value }\end{array}$ \\
\hline 1. Lymphocytes $\mathrm{T}\left(\% \mathrm{CD}^{+}\right)$ & & & .303 & .024 \\
\hline FA level of exposure & 14.092 to 55.191 & .002 & & \\
\hline Females vs. males & -4.570 to 11.131 & .400 & & \\
\hline Smokers vs. nonsmokers & -9.623 to 5.928 & .631 & & \\
\hline Age (yr) & -0.371 to 0.380 & .981 & & \\
\hline 2. T-helper cells $\left(\% \mathrm{CD} 4^{+}\right)$ & & & .280 & .037 \\
\hline FA level of exposure & 8.907 to 47.963 & .006 & & \\
\hline Females vs. males & -4.366 to 10.554 & .404 & & \\
\hline Smokers vs. nonsmokers & -2.009 to 12.769 & .147 & & \\
\hline Age (yr) & -0.429 to 0.285 & .682 & & \\
\hline 3. NK cells $\left(\% \mathrm{CD} 16-56^{+}\right)$ & & & .500 & $<.001$ \\
\hline FA level of exposure & -98.593 to -6.821 & $<.001$ & & \\
\hline Females vs. males & -2.604 to 1.066 & .084 & & \\
\hline Smokers vs. nonsmokers & -1.255 to 2.190 & .270 & & \\
\hline Age (yr) & -1.027 to 1.022 & .820 & & \\
\hline
\end{tabular}

$p<0.05$, significantly different.

individuals occupationally exposed to FA is well established. Suruda et al. (1993) found elevated frequencies of $\mathrm{MN}$ in lymphocytes (26\%), nasal epithelial cells (22\%), and buccal mucosa cells (12-fold) in a group of mortician students, before and after attending an embalming course. A dose-response relationship was observed with cumulative exposure to FA. In a population of 151 workers exposed to FA from two plywood factories, Yu et al. (2005) reported a significantly higher frequency of $M N$ in peripheral lymphocytes. Further, a higher frequency of $\mathrm{MN}$ in lymphocytes was observed in pathology anatomy lab workers in two independent Portuguese studies (Costa et al., 2008; Viegas et al., 2010). Orsière et al. (2006) found a significantly higher frequency of monocentromeric $\mathrm{MN}$ in FA-exposed workers, suggesting an aneugenic effect of FA. However, recent studies by Costa et al. (2011) of FA-exposed pathology anatomy workers and by Speit et al. (2011) in mammalian cell lines indicated a clastogenic effect attributed to FA as the primary mechanism underlying $\mathrm{MN}$ formation, confirming previous reports (Titenko-Holland et al., 1996).

Our results on SCE frequency also agree with data from other studies that also reported a higher frequency of this cytogenetic biomarker in FA exposed workers. Yager et al. (1986) were the first to describe a rise in SCE in the peripheral lymphocytes of FA-exposed individuals. SCE were measured in blood samples collected from 8 nonsmoking anatomy students before and after a 10-wk anatomy class with a mean FA concentration in breathing-zone samples of $1.2 \mathrm{ppm}$. The results showed that SCE frequency was significantly higher in samples taken at the end of the course compared to samples obtained from the same individuals immediately before FA exposure began. Shaham et al. (1997, 2002) examined a group of 90 pathology workers. Based on different FA exposure levels, the exposed group was divided into a low-exposure group (0.04 to $0.7 \mathrm{ppm}$ ) and a high-exposure group (0.72 to $5.6 \mathrm{ppm}$ ). Both exposed groups displayed significantly higher SCE frequencies. Ye et al. (2005) examined two different groups of FA-exposed workers. One group was composed of 18 workers in a FA manufacturing facility (8-h TWA level of exposure was $0.82 \pm 0.24 \mathrm{ppm})$, whereas the second group included 16 waiters who were exposed to low levels of FA while working in a new ballroom for $12 \mathrm{wk}$ (5-h TWA level of exposure was $0.09 \pm 0.05 \mathrm{ppm}$ ). The first group showed a significantly elevated frequency of SCE in lymphocytes, whereas no significant difference was found in waiters, probably due to the low level of exposure to FA. Finally, Costa 
et al. (2008) in a group of pathology anatomy workers (TWA $=0.44 \mathrm{ppm}$ ) also noted a 1.4-fold increase in SCE frequency. However, other investigators did not find greater SCE rates in subjects occupationally exposed to FA (Thomson et al., 1984; Suruda et al., 1993; Ying et al., 1999). In the current study no significant differences were found in TCR-Mf. To our knowledge this is the first report in which TCRMf was evaluated in workers exposed to FA. Thus, more studies are needed to confirm these findings.

The immunological status of exposed and control subjects was also addressed by assessing percent of different lymphocyte subsets in peripheral blood. The reference values for lymphocyte subsets in Caucasian population are $60-87 \%$ for total $\mathrm{CD}^{+}{ }^{+} \mathrm{T}$ lymphocytes, $32-61 \%$ for $\mathrm{CD}^{+}{ }^{+} \mathrm{T}$ helper cells, $14-43 \%$ for CD8 $^{+}$T cytotoxic cells, 5-20\% for CD19+ $B$ cells, and $4-28 \%$ for NK cells $\left(\mathrm{CD} 16^{+}\right.$ $56^{+}$) (Santagostino et al., 2009). Our results in both groups are within these expected ranges and also in accordance with recent data in a Portuguese population (García-Lestón et al., 2011).

Regarding the FA-exposure effect when comparing both groups, no statistical differences were found for total $\% \mathrm{CD}^{+} \mathrm{T}$ lymphocytes, \%CD4 ${ }^{+} \mathrm{T}$ helper cells (Th), $\% \mathrm{CD}^{+}{ }^{+}$cytotoxic cells (Tc), Th/Tc ratio, and $\%$ CD16-56 ${ }^{+}$NK cells. However a significant decrease of percent $B$ cells was found in the exposed group. In addition, a nearly significant correlation obtained between SCE and B cells indicates a reliable association between these two parameters influenced by FA exposure.

Our results are in agreement with other studies which showed that FA exposure may affect immunological parameters. Tang et al. (2009) summarized eight Chinese studies concerning FA-induced hematotoxicity. The majority of these reports noted a decrease in total white blood cells (WBC) counts in FA-exposed workers. In one of the studies concerning clinical pathology personnel (FA levels were between 0.2 and 0.8 ppm). Tang et al. (2009) found that a significantly higher proportion of the exposed subjects (14\%) showed abnormal
WBC counts compared to controls (5\%). In a recent study on the ability of FA to disrupt hematopoiesis in a group of exposed workers with mean FA 8-h TWA of 1.28 ppm, Zhang et al. (2010) also reported a significant reduction in WBC counts, granulocytes, and lymphocytes. However, there are also studies where WBC counts were not markedly influenced by FA exposure (Madison et al., 1991; Tang et al., 2009).

In our study a decreased percentage of B cells was found in exposed individuals, suggesting immunosuppression and therefore a reduced immune response. B cells are involved in organism humoral responses against antigens and are also engaged in adaptive immune responses. Further, \%CD16-56 ${ }^{+}$NK cells were inversely correlated with FA levels of exposure. NK cells are effector lymphocytes of the innate immune system that control several types of tumors and microbial infections by limiting their spread and subsequent tissue damage (Vivier et al., 2009). Indeed, several studies describe a reduced resistance to infections, including upper respiratory tract infections, recurrent rhinitis, and pneumonitis in individuals occupationally exposed to FA. In the study by Zhang et al. (2010), 40\% of the exposed subjects had recent respiratory infections. Evidence suggests that FA exposure may result in functional changes in neutrophils and possibly influence the host capacity to respond to infections (Lyapina et al., 2004). Lyapina et al. (2004) tested this hypothesis by measuring neutrophil respiratory burst activity (NRBA) in 29 workers exposed to FA (mean FA level 0.71 $\pm 0.32 \mathrm{ppm}$ ). Exposed workers displayed a significant rise in upper respiratory tract inflammations, but no significant differences were found between groups in spontaneous or stimulated NRBA assays.

In a population-based case-control study conducted by Hildesheim et al. (2001), the risk of nasopharyngeal carcinoma and ever exposure to FA was higher among Epstein-Barr virus (EBV) seropositive individuals than among nonseropositive subjects. Viral-associated cancers are increased in immunosuppressed individuals, due most likely to the inability of 
the organism to limit viral replication and/or expansion of infected cells (Schulz, 2009). Epstein-Barr virus (EBV) is implicated in the etiology of nasopharyngeal carcinoma (Marsh et al., 2007; Bosetti et al., 2008). Thompson and Grafstrom (2009) suggested that FA may exert an indirect influence in EBV reactivation through deregulation of nitrosothiol homeostasis and may also interact with the virus to promote epithelial cell transformation.

Although our results are in agreement with published data, lymphocyte subpopulations were affected differently in some other studies. Ying et al. (1999) assessed the lymphocyte subsets in 23 nonsmoking medical students exposed to FA during an 8-wk anatomy lab course (8-h TWA $=0.413 \pm 0.243$ ppm) and found a significant increase in B cells and a significant fall in total $\mathrm{T}$ cells, $\mathrm{T}$-helper-inducer cells, and T-cytotoxic-suppressor cells at the end of the study. A similar result was reported by Ye et al. (2005) for a group of workers from a FA manufacturing facility. In a recent cross-sectional study conducted in China, a decreased in NK cells, regulatory T cells, and CD8 effector memory $T$ cells was reported among FA-exposed workers (Hosgood et al., 2012). The small sample size or/and higher FA level of exposure may have contributed to the different outcomes observed between these and the present study.

Another important factor that may also explain the different results is individual susceptibility. One of the enzymes involved in FA detoxification is the mitochondrial aldehyde dehydrogenase-2 (ALDH2) (Teng et al., 2001). $A L D H 2$ gene contains an inactive $A L D H 2 * 2$ allele; the presence of the mutant allele leads to a decrease or absence of ALDH2 catalytic activity (Brennan et al., 2004). Approximately $50 \%$ of East Asians carry the mutant inactive $\mathrm{ALDH}_{2}{ }^{2} 2$ null allele (Goedde et al., 1992; Oota et al., 2004), whereas nearly all Caucasians carry the functional ALDH2*1/1 genotype (Chambers et al., 2002; Brennan et al., 2004). Thus, larger human studies combining genotoxic, immunological parameters and susceptibility biomarkers are needed in order to understand the potential relationship between FA exposure and these endpoints.
Finally, significant associations were found between FA level of exposure and total \%CD3 ${ }^{+}$ T lymphocytes, \%CD4 ${ }^{+}$Th cells, and \%CD16$56^{+}$NK cells in exposed individuals, indicating a reliable relationship between level of exposure and alterations in these immunological markers. Regarding the influence of lifestyle factors and exposure time on the endpoints studied, in this study no significant influence of gender, smoking habits, or years of employment was observed. Age was the only confounder that showed a significant influence but only with respect to SCE frequency. This effect was confirmed with the significant positive correlation noted between age and SCE frequency. Our data agree with previous studies (KirschVolders et al., 2006; Teixeira et al., 2010) reporting a positive association between age and cytogenetic biomarkers related to a progressive increase in spontaneous chromosome instability and loss of efficiency in DNA repair mechanisms, which may result in accumulation of genetic lesions with increasing age (Bolognesi et al., 1999).

\section{CONCLUSIONS}

Data obtained in this study indicate that increased genotoxic risk due to FA occupational exposure cannot be excluded. $\mathrm{MN}$ and SCE frequencies were significantly elevated in peripheral lymphocytes of pathology anatomy workers exposed to FA. A significant decrease of percentage of B cells in exposed group was also found. Further, a significant relationships between FA level of exposure and increases in \%total $\mathrm{T}$ lymphocytes and \%Th-cells and fall in \%NK cells were noted in exposed individuals, indicating that FA exposure may influence immunological parameters. However, these results need to be interpreted with caution, owing to the relatively low number of exposed and control individuals included in this study.

\section{REFERENCES}

ACGIH, 2008. TLV's and BEI's-Based on the documentation of the threshold limit values 
for chemical substances and physical agents \& biological exposure indices. Cincinnati, $\mathrm{OH}$ : American Conference of Governmental Industrial Hygienists.

Akbar-Khanzadeh, F., and Pulido, E. V. 2003. Using respirators and goggles to control exposure to air pollutants in an anatomy laboratory. Am. J. Ind. Med. 43: 326-331.

Akiyama, M., Umeki, S., Kusunoki, Y., Kyoizumi, S., Nakamura, N., and Mori, T. 1995. Somatic-cell mutations as a possible predictor of cancer risk. Health Phys. 68: 643-649.

Bolognesi C., Lando C., Forni A., Landini E., Scarpato R., Migliore L., and Bonassi S. 1999. Chromosomal damage and ageing: Effect on micronuclei frequency in peripheral blood lymphocytes. Age Ageing. 28: 393-397.

Bonassi, S., Ugolini, D., Kirsch-Volders, M., Strömberg, U., Vermeulen, R., and Tucker, J. D. 2005. Human population studies with cytogenetic biomarkers: Review of the literature and future prospectives. Environ. Mol. Mutagen. 45: 258-270.

Bosetti, C., McLaughlin, J. K., Tarone, R. E., Pira, E., and La Vecchia, C. 2008. Formaldehyde and cancer risk: A quantitative review of cohort studies through 2006. Ann Oncol 19: 29-43.

Brennan, P., Lewis S., Hashibe, M., Bell, D. A., Boffetta, P., Bouchardy, C., Caporaso, N., Chen, C., Coutelle, C., Diehl S. R., Hayes, R. B., Olshan, A. F., Schwartz, S. M., Sturgis, E. M., Wei Q., Zavras, A. I., and Benhamou, S. 2004. Pooled analysis of alcohol dehydrogenase genotypes and head and neck cancer: A HuGE review. Am. J. Epidemiol. 159: $1-16$.

Carrano, A., and Natarajan, A., 1988. Considerations for population monitoring using cytogenetic techniques. Mutat. Res. Human Monitoring (special issue) 204: 379-406.

Chambers, G. K., Marshall, S. J., Robinson, G. M., Maguire, S., Newton-Howes, J., and Chong, N. L. 2002. The genetics of alcoholism in Polynesians: Alcohol and aldehyde dehydrogenase genotypes in young men. Alcohol Clin. Exp. Res. 26: 949-55.
Checkoway, H., Boffetta, P., Mundt, D. J., and Mundt, K. A. 2012. Critical review and synthesis of the epidemiologic evidence on formaldehyde exposure and risk of leukemia and other lymphohematopoietic malignancies. Cancer Causes Control. doi:10.1007/s10552-012-0055-2.

Costa, S., Coelho, P., Costa, C., Silva, S., Mayan, O., Santos, L. S., Gaspar, J., and Teixeira, J. P. 2008. Genotoxic damage in pathology anatomy laboratory workers exposed to formaldehyde. Toxicology 252: 40-48.

Costa, S., Pina, C., Coelho, P., Costa, C., Silva, S., Porto, B., Laffon, B., and Teixeira, J. P. 2011. Occupational exposure to formaldehyde: genotoxic risk evaluation by comet assay and micronucleus test using human peripheral lymphocytes. J Toxicol Environ Health A 74: 1040-1051.

Fenech, M., 1993. The cytokinesis-block micronucleus technique and its application to genotoxicity studies in human populations. Environ. Health Perspect. 101: 101-107.

Fenech, M. 2007. Cytokinesis-block micronucleus cytome assay. Nat. Protocol 2: 1084-1104.

García-Lestón, J., Roma-Torres, J., Vilares, M., Pinto, R., Cunha, L. M., Prista, J., Teixeira, J. P., Mayan, O., Pásaro, E., Méndez, J., and Laffon, B. 2011. Biomonitoring of a population of Portuguese workers exposed to lead. Mutat. Res.18: 81-88.

Goedde, H. W., Agarwall, D. P., Fritze, G., Meier-Tackmann, D., Singh, S., Beckmann, G., Bhatia, K., Chen, L. Z., Fang, B., and Lisker, R. 1992. Distribution of $A D H 2$ and $A L D H 2$ genotypes in different populations. Human Genet. 88: 344-346.

Hildesheim, A., Dosemeci, M., Chan, C. C., Chen, C. J., Cheng, Y. J., Hsu, M. M., Chen, I. H., Mittl, B. F., Sun, B., Levine, P. H., Chen, J. Y., Brinton, L. A., and Yang, C. S. 2001. Occupational exposure to wood, formaldehyde, and solvents and risk of nasopharyngeal carcinoma. Cancer Epidemiol. Biomarkers Prev. 10: 1145-1153.

Hosgood, H. D. 3rd, Zhang, L., Tang, X., Vermeulen, R., Hao, Z., Shen, M., Qiu, C., 
Ge, Y., Hua, M., Ji, Z., Li, S., Xiong, J., Reiss, B., Liu, S., Xin, K. X., Azuma, M., Xie, Y., Freeman, L. B., Ruan, X., Guo, W., Galvan, N., Blair, A., Li, L., Huang, H., Smith, M. T., Rothman, N., and Lan, Q. 2012. Occupational exposure to formaldehyde and alterations in lymphocyte subsets. Am. J. Ind. Med. doi:10.1002/ajim.22088.

IARC. 2006. Formaldehyde, 2-butoxyethanol and 1-tert-butoxy-2-propanol. IARC Monogr. Eval. Carcinogen. Risks Hum. 88. Lyon, France: World Health Organization.

Kirsch-Volders, M., Mateuca, R. A., Roelants, M., Tremp, A., Zeiger, E., Bonassi, S., Holland, N., Chang, W. P., Aka, P. V., Deboeck, M., Godderis, L., Haufroid, V., Ishikawa, H., Laffon, B., Marcos, R., Migliore, L., Norppa, H., Teixeira, J. P., Zijno, A., and Fenech, M. 2006. The effects of GSTM1 and GSTT1 polymorphisms on micronucleus frequencies in human lymphocytes in vivo. Cancer Epidemiol. Biomarkers Prev. 15: 1038-1042.

Laffon, B., Teixeira, J. P., Silva, S., Roma-Torres, J., Pérez-Cadahía, B., Méndez, J., Pásaro, E., and Mayan, O. 2006. Assessment of occupational genotoxic risk in the production of rubber tyres. Ann. Occup. Hyg. 50: 583-592.

Lu, K., Boysen, G., Gao, L., Collins, L. B., and Swenberg, J. A. 2008. Formaldehydeinduced histone modifications in vitro. Chem. Res. Toxicol. 21: 1586-1593.

Luebke, R. W., Chen, D. H., Dietert, R., Yang, Y., and Luster, M. I., with Immunotoxicology Workshop. 2006. The comparative immunotoxicity of five selected compounds following developmental or adult exposure. J. Toxicol. Environ. Health B 9: 1-26.

Lyapina, M., Zhelezova, G., Petrova, E., and Boev, M. 2004. Flow cytometric determination of neutrophil respiratory burst activity in workers exposed to formaldehyde. Int. Arch. Occup. Environ. Health 77: 335-340.

Madison, R. E., Broughton, A., and Thrasher, J. D. 1991. Immunologic biomarkers associated with an acute exposure to exothermic byproducts of a urea formaldehyde spill. Environ. Health Perspect. 94: 219-223.
Marsh, G. M., Youk, A. O., and Morfeld, P. 2007. Mis-specified and non-robust mortality risk models for nasopharyngeal cancer in the National Cancer Institute formaldehyde worker cohort study. Regul. Toxicol. Pharmacol. 47: 59-67.

Mayeux., R. 2004. Biomarkers: Potential uses and limitations. NeuroRx 1: 182-188.

National Toxicology Program. 2010. Final report on carcinogens background document for formaldehyde. Rep. Carcinogen Background Doc. 10-5981:i-512.

National Institute for Occupational Safety and Health. 1994. Formaldehyde: Method 3500 (Issue 2). In NIOSH manual of analytical methods, 2-5. Cincinnati, OH: U.S. Department of Health and Human Services.

Oota, H., Pakstis, A. J., Bonne-Tamir, B., Goldman, D., Grigorenko, E., Kajuna, S .L., Karoma, N. J., Kungulilo, S., Lu, R. B., Odunsi, K., Okonofua, F., Zhukova, O. V., Kidd, J. R., and Kidd, K. K. 2004. The evolution and population genetics of the ALDH2 locus: Random genetic drift, selection, and low levels of recombination. Ann. Hum. Genet. 68: 93-109.

Orsière, T., Sari-Minodier, I., Iarmarcovai, G., and Botta, A. 2006. Genotoxic risk assessment of pathology and anatomy laboratory workers exposed to formaldehyde by use of personal air sampling and analysis of DNA damage in peripheral lymphocytes. Mutat. Res. 605: 30-41.

Paustenbach, D., Alarie, Y., Kulle, T., Schachter, N., Smith, R., Swenberg, J., Witschi, P., and Horowitz, S. B., 1997. A recommended occupational limit for formaldehyde based on irritation. J. Toxicol. Environ. Health 50: 217-263.

Perry, P., and Wolff, S., 1974. New Giemsa method for the differential staining of sister chromatids. Nature 251: 156-158.

Santagostino, A., Garbaccio, G., Pistorio, A., Bolis, V., Camisasca, G., Pagliaro, P., and Girotto, M. 1999. An Italian national multicenter study for the definition of reference ranges for normal values of peripheral blood lymphocyte subsets in healthy adults. Haematologica 84: 499-504. 
Schulz, T. F. 2009. Cancer and viral infections in immunocompromised individuals. Int. J. Cancer 15: 1755-1763.

Shaham, J., Bomstein, Y., Meltzer, A., and Ribak, J. 1997. DNA-protein crosslinks and sister chromatid exchanges as biomarkers of exposure to formaldehyde. Int. J. Occup. Environ. Health 3: 95-104.

Shaham, J., Gurvich, R., and Kaufman, Z. 2002. Sister chromatid exchanges in pathology staff occupationally exposed to formaldehyde. Mutat. Res. 514: 115-123.

Speit, G., Kahner, S., Linsenmeyer, R., and Schatz, P. 2011. Does formaldehyde induce aneuploidy? Mutagenesis 26: 805-811.

Suruda, A., Schulte, P., Boeniger, M., Hayes, R. B., Livingston, G. K., and Steenland, K., 1993. Cytogenetic effects of formaldehyde exposure in students of mortuary science. Cancer Epidemiol. Biomarkers Prev. 2: 453-460.

Tang, X., Bai, Y., Duong, A., Smith, M.T., Li, L., and Zhang, L. 2009. Formaldehyde in China: Production, consumption, exposure levels, and health effects. Environ. Int. 35: 1210-1224.

Teixeira, J., Gaspar, J., Silva, S., Torres, J., Silva, S., Azevedo, M., Neves, P., Laffon, B., Mendez, J., Goncalves, C., Mayan, O., Farmer, P., and Rueff, J. 2004. Occupational exposure to styrene: modulation of cytogenetic damage and levels of urinary metabolites of styrene by polymorphisms in genes CYP2E1, EPHX1, GSTM1, GSTT1 and GSTP1. Toxicology 195: 231-242.

Teixeira, J. P., Gaspar, J., Coelho, P., Costa, C., Pinho-Silva, S., Costa, S., Da Silva, S., Laffon, B., Pásaro, E., Rueff, J., and Farmer, P. 2010. Cytogenetic and DNA damage on workers exposed to styrene. Mutagenesis 25: 617-621.

Teng, S., Beard, K., Pourahmad, J., Moridani, M., Easson, E., Poon, R., and O'Brian, P. J. 2001. The formaldehyde metabolic detoxification enzyme systems and molecular cytotoxic mechanism in isolated rat hepatocytes. Chem. Biol. Interact. 130-132: 285-296.
Thompson, C., and Grafstrom, R. 2009. Commentary: mechanistic considerations for associations between formaldehyde exposure and nasopharyngeal carcinoma. Environ. Health 8: 53.

Thomson, E. J., Shackleton, S., and Harrington, J. M. 1984. Chromosome aberrations and sister-chromatid exchanges frequencies in pathology staff occupationally exposed to formaldehyde. Mutat. Res. 141: 89-93.

Titenko-Holland, N., Levine, A. J., Smith, M. T., Quintana, P. J., Boeniger, M., Hayes, R., Suruda, A., and Schulte, P. 1996. Quantification of epithelial cell micronuclei by fluorescence in situ hybridization (FISH) in mortuary science students exposed to formaldehyde. Mutat. Res. 371: 237-248.

Veraldi, A., Costantini, A. S., Bolejack, V., Miligi, L., Vineis, P., and van Loveren, $\mathrm{H}$. 2006. Immunotoxic effects of chemicals: A matrix for occupational and environmental epidemiological studies. Am. J. Ind. Med. 49: 1046-1055.

Viegas, S., Ladeira, C., Nunes, C., Malta-Vacas, J., Gomes, M., Brito, M., Mendonca, P., and Prista, J. 2010. Genotoxic effects in occupational exposure to formaldehyde: A study in anatomy and pathology laboratories and formaldehyde-resins production. J. Occup. Med. Toxicol. 5: 25.

Vivier, E., Tomasello, E., Baratin, M., Walzer, T., and Ugolini, S. 2009. Functions of natural killer cells. Nat. Immunol. 9: 503-510.

Yager, J. W., Cohn, K. L., Spear, R. C., Fisher, J. M., and Morse, L., 1986. Sister-chromatid exchanges in lymphocytes of anatomy students exposed to formaldehyde-embalming solution. Mutat. Res. 174: 135-139.

Ye, X., Yan, W., Xie, H., Zhao, M., and Ying, C., 2005. Cytogenetic analysis of nasal mucosa cells and lymphocytes from high-level longterm formaldehyde exposed workers and low-level short-term exposed waiters. Mutat. Res. 588: 22-27.

Ying, C. J, Ye, X. L., Xie, H., Yan, W. S., Zhao, M. Y., Xia, T., and Yin, S. Y. 1999. Lymphocyte subsets and sister-chromatid exchanges in the students exposed to formaldehyde vapor. Biomed. Environ. Sci. 12: 88-94. 
Yu, L. Q., Jiang, S. F., Leng, S. G., He, F. S., and Zheng, Y. X. 2005. Early genetic effects on workers occupationally exposed to formaldehyde. Chin. J. Prev. Med. 39: 392-395.
Zhang, L., Freeman, L. E., Nakamura, J., Hecht, S. S., Vandenberg, J. J., Smith, M. T., and Sonawane, B. R. 2010. Formaldehyde and leukemia: Epidemiology, potential mechanisms, and implications for risk assessment. Environ. Mol. Mutagen. 51: 181-191. 